北海道の栽培に適したジャガイモシストセンチュウ抵抗性，生食・調理加工用品種 「キタアカリ」「とらや」「さやか」の育成

農研機構北海道農業研究センターバレイショ育種グループ (代表 森 元幸 1,2$)$ )

1) 農研機構北海道農業研究センター, 北海道河西郡芽室町, 干 082-0081

2) 現 : カルビーポテト (株) 馬鈴薯研究所, 北海道河西郡芽室町, ₹ 082-0006

\title{
Breeding of potato varieties with resistance to potato cyst nematode and suitable for cooking and processing, "Kita-akari" "Touya" and "Sayaka" in Hokkaido
}

Potato breeding group of NARO Hokkaido Agricultural Research Center (Representative; Motoyuki Mori ${ }^{1,2)}$ )

1) NARO Hokkaido Agricultural Research Center, Memuro-cho, Kasai-gun, Hokkaido 082-0081, Japan

2) Present address: Calbee Potato, Inc. Potato Research Center, Memuro-cho, Kasai-gun, Hokkaido 082-0006, Japan

キーワード

バレイショ，ジャガイモシストセンチュウ，キタアカリ，とうや，さやか，生食用，調理加工用

\section{1. はじめに}

バレイショに寄生するシストセンチュウは, ジャガイ モシストセンチュウ（Globodera rostochiensis）とジャガ イモシロシストセンチュウ (G. pallida) の 2 種類が知ら れて打り，ヨーロッパ，南米各国など 50 力国以上で分布 が認められている（Brodie 2001）。シストセンチュウは土 壌中に生息し, バレイショの根に寄生して湌分を吸収し, 線虫密度が高くなると大幅な減収を引き起こす。シスト (卵のら) は自然条件の土壤中で 10 年以上も卵の活性を 維持し，シストが付着した生産物や土と共に移動して伝 染が拡大寸る。このため世界的にも植物検疫上で第一級 の有害線虫とされ，污染圃場での採種栽培が禁止される などバレイショ生産体系に大きな障害となっている。わ が国では, 1972 年に北海道虬田郡真狩村で, 初めてジャ ガイモシストセンチュウ（以下 Gr）の発生が確認された (稲垣 1984). その後, 1977 年には初発生地から東へ約 $300 \mathrm{~km}$ 離れた斜里郡清里町でも分布が認められ, 1992 年 には長崎県でも発生が確認された。 さらに 2003 年には青 森県，そして 2007 年には三重県でも発生を確認し全国的 に広がった。近年は道内でも新規発生場所の確認が相次 ぐなど，発生地域の拡大が問題となっており，全国の発 生面積は 1 万 ha を超え, さらに増加傾向にある.なお日 本で発生している Gr のパソタイプ（レース）はRo1の

2018 年 10 月 12 日受領 日本育種学会賞受賞 (第 137 号) 2018 年 11 月 9 日 J-STAGE 早期公開

Correspondence: m_mori@calbee-potato.co.jp
みであり，他のパソタイプは確認されていない（串田・ 百田 2005).

$\mathrm{Gr}$ 発生が確認された 1970 年代前半は, バレイショの 一人当たり年間消費量が最低の約 $13 \mathrm{~kg}$ となった時期と 重なる．食料として生いもを家庭で調理する生食（青果） 向け消費が減少したためである。ところが消費の現場で は質的な変化が生じ，1970年に開催された大阪万博 EXPO’70 のレストランでフライドポテトが人気を博した ように油で揚げる用途が生まれ，加工食品向けが加わり バレイショの消費量は増加へ転じた. 1970 年代にポテト チップ, そして 1980 年代に冷凍フライドポテトの増加に 続き, レストランチェーンなど外食産業の発展, さらに 1990 年頃からは惣菜等の中食としてコロッケとサラダの 消費が拡大した（森 2015）。2000 年頃には一人当たり年 間消費量が約 $18 \mathrm{~kg}$ まで盛り返したが, 近年では $16 \mathrm{~kg}$ 程 度の水準で推移している。一方，バレイショは栄養繁殖 性でありイネやコムギなどの種子繁殖性に比べその増殖 率は 10 倍程度と低く, 水分が $70 \%$ 程度と高いため保存 性が悪く, 生理的な齢が変化する種いもは越年在庫でき ない.さらに耕作地 $10 \mathrm{a}$ 当たりの種いも重量は通常 $200 \mathrm{~kg}$ であり, 種子繁殖性の 10 倍以上の必要量となり, 特別な貯蔵庫での管理を要する等の理由から種苗コスト が高い。このため新品種の普及には多額の経費と長い年 数を要し, 生食用の主要品種は現在でも 100 年以上前に 外国から導入した「男爵薯」と「メークイン」である. 「新じゃが」として春から出回る「ニシュタカ」, ポテト チップ原料となる「トヨシロ」，そしてでん粉原料用の 「コナフブキ」など，1985 年以前に育成された総ての国 
産品種は $\mathrm{Gr}$ に対し抵抗性を持たない。このため, 生産 側から Gr 抵抗性品種が，実需側からは調理加工時に歩 留りの高い品種が，強く望まれていた。

\section{Gr 抵抗性品種の効果と育種戦略}

Gr のシスト中には 200〜500 個の卵があり, バレイショ の根から分泌された物質に反応して孵化し, 幼虫が根に 侵入する。この卵は経年で約 $70 \%$ が活性を維持し，孵化 するまで 10 年以上も生存してバレイショの根を待ち続け る。根に侵入した幼虫は，ホルモン様物質を分泌して線 虫頭部付近に巨大細胞を形成させ，ここから栄養を吸収 して成長する。根の内部に寄生した幼虫が養分を吸収す るとバレイショの生育は停滞し, 高密度戋場では下葉か ら枯れ上がり収量は半減する。交尾後の雌成虫は球状の 虫体の大部分を根表面に露出した状態となり，体内に卵 を形成し体表皮は徐々にタンニン化して死に，直径約 $0.6 \mathrm{~mm}$ のシストを形成する。北海道では 60 日程度で 1 世代を経過する（相場・稲垣 1992）。

污染戋場に $\mathrm{Gr}$ 抵抗性品種を栽培した場合, 卵が孵化 して幼虫が根に侵入するまでは罹病性品種と同じである. その後根中に巨大細胞を形成できないため, 幼虫は餓死 する（村山 1981）。このように抵抗性品種を栽培すると シスト内の卵を捊化させ幼虫をすべて死滅させることか ら, 農薬を用いた化学的防除を行わなくても土壌中の線 虫密度を大幅低下させら机る（図 1，表 1)。さらに生 産されたいも（塊菱）にシストが付着しないため，生産 物の流通による発生面積の拡大を抑制できる（山田 1987).

Gr の発生確認と同時に, 当時の農林水産省北海道農業

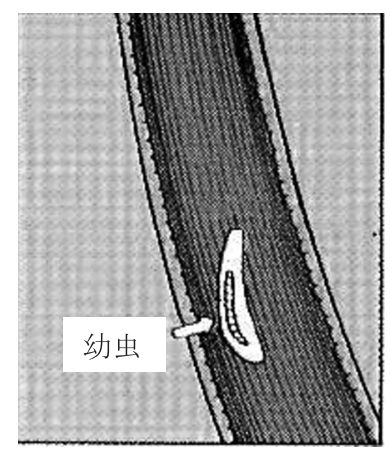

抵抗性品種

ふ化した幼虫は根に進入 するが, 幼虫は栄養を吸 収することができず，シ ストまで成熟できず死ぬ.

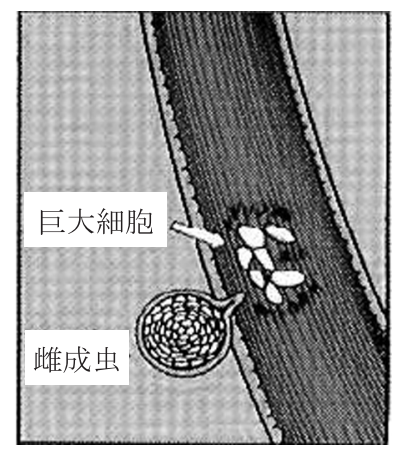

感受性品種
根に進入した幼虫の回り に巨大細胞ができ養分を 吸収し, 雌成虫は口辺を 残して体は根外に飛び出 しシストとなる。
図 1. シストセンチュウ抵抗性品種の効果と抵抗性のメカニズ 么.

注. 村山（1981）原図より改変.
表 1. Gr 発生圃場に打けるバレイショ栽培前後の健全卵数の 変化

\begin{tabular}{lccc}
\hline \hline \multirow{2}{*}{ 品種名 } & \multicolumn{3}{c}{ 乾土 $1 \mathrm{~g}$ 当たり健全卵数 } \\
\cline { 2 - 4 } & 植付期 & 収穫期 & 増減比 $(\%)$ \\
\hline Tunika & 250 & 72 & 31 \\
農林 1 号 & 278 & 552 & 199 \\
紅丸 & 342 & 687 & 200 \\
\hline
\end{tabular}

調査 : 道立中央農業試験場, 1975 1977 年.

場所 : 北海道虬田郡真狩村.

試験場では北海道立農業試験場の協力のもと, 総合防除 の基幹となる抵抗性品種育成に着手し, 次のように研究 を展開した（西部・稲垣 1980）.

(1)既存の国内品種の中に抵抗性品種がないか探索

(2)外国の抵抗性品種を導入評価して直接利用

(3)抵抗性遺伝資源を探索導入し国内品種に抵抗性を付与 した新品種を育成

(4)異種等の発生に備兄来歴の異なる抵抗性遺伝資源を導 入して母本を育成

(1)と(2)が比較的短期間で一応の目的を達成でき，(3)は 目的達成までに長期間を要するが抵抗性以外の形質も改 良した品種を育成できる利点があり，(4)は将来への備え である。

北海道産 Gr に対し抵抗性を保有するかどらか，遺伝資 源について線虫抵抗性検定を行ったところ，実用性を有 する国内品種，保存育成系統拈よび外国品種の中から抵 抗性を見出せず，近縁野性種や種間雑種系統の一部に抵 抗性を認めたの反であった。つづいて，主にヨーロッパ から「Tunika」,「Skutella」,「Prevalent」,「Ehud」,「Mara」 および「Prominent」などの抵抗性品種を導入し，生育特 性と生産力を評価すると共に $\mathrm{Gr}$ 発生地带に扔ける適応性 を検討した。 これにより「Tunika」は，Gr 発生地帯の主 要品種「紅丸」および「農林 1 号」に代わるでん粉原料 用抵抗性品種として認められ，1978 年「ッニカ（ばれい しょ導入 3 号)」として命名登録され，北海道における奨 励品種に採用された（西部・稲垣 1980）。乙かし Gr 発生 地帯でもあまり普及せず, 1982 年の 69 ha を最高に栽培 面積はその後減少した.

な打「Tunika」が保有する単一優性遺伝子 $\mathrm{H}_{1}$ は, アン デス原産 4 倍体栽培バレイショSolanum tuberosum ssp. andigena に由来し, Grのパソタイプ (レース) Rol に対 して完全な抵抗性を示すことが知られている(Ross 1986).

\section{Gr 抵抗性検定法の改良と効率的な抵抗性母 本の育成}

当初, 抵抗性個体の選抜は, 交配種子を播種して養成 した実生を，Grの污染土壤で直接栽培する「幼苗検定 法」によった。 この方法では, 抵抗性個体の無線虫化の ために, 通常の育種過程より 1 年多く要する難点があっ 
た。これを解決する方法として，「ペア塊茎法」を開発し その後は本法によった（図 2)。実生個体をポットで養成 し，同一株から収穫された 2 個の塊茎に同じ番号を付し 2 群に分け，一方を線虫抵抗性の検定に用い，他方を種 いもとして保存する。検定の結果，抵抗性が認吼た 個体のみを以降の選抜に供する。この方法により，育種 年限を 1 年延ばすことなく線虫抵抗性検定が可能となり, 効率的な抵抗性の早期選抜ができるようになった（西部・ 稻垣 1980).

$\lceil$ Tunika」や「Skutella」なぞの抵抗性品種と感受性品 種の後代に打祆抵抗性個体出現率は, 交配組合せによ り $16.7 \%$ から $60.8 \%$ まで変動したが平均は $45.4 \%$ であっ た（稲垣 1980）。このことから抵抗性と感受性とはほぼ 1 対 1 亿分離するものと考兄られ，抵抗性遺伝子型は一 重式 $\left(\mathrm{H}_{1} \mathrm{~h}_{1} \mathrm{~h}_{1} \mathrm{~h}_{1}\right)$ と示唆された。 これは初期世代で半数以 上を棄却することを意味し，選抜効率の向上が望ま机た。 「Tunika」などは抵抗性遺伝子を1つしか持たない一重式 であるため, 後代の抵抗性個体出現率は約 $50 \%$ と考兄ら れ，初期世代で半数以上を棄却することになった。 この ため選抜効率を高めるためには, 抵抗性遺伝子を複数有 する母本系統の育成が不可欠であった。 アメリカ合衆国 コーネル大学から抵抗性遺伝子が 2 重式 $\left(\mathrm{H}_{1} \mathrm{H}_{1} \mathrm{~h}_{1} \mathrm{~h}_{1}\right)$ と 1 重式 $\left(\mathrm{H}_{1} \mathrm{~h}_{1} \mathrm{~h}_{1} \mathrm{~h}_{1}\right)$ の組合せである交配種子「Hudson $\times$ Wauseon」（R392）を導入し, 選抜系統の後代検定により 抵抗性遺伝子を 3 重式 $\left(\mathrm{H}_{1} \mathrm{H}_{1} \mathrm{H}_{1} \mathrm{~h}_{1}\right)$ 飞持つ「R392-50」を 選定した（表 2)。「R392-50」を交配親とする組合せで は, 後代の 96.4\%以上が抵抗性であると期待されるため,

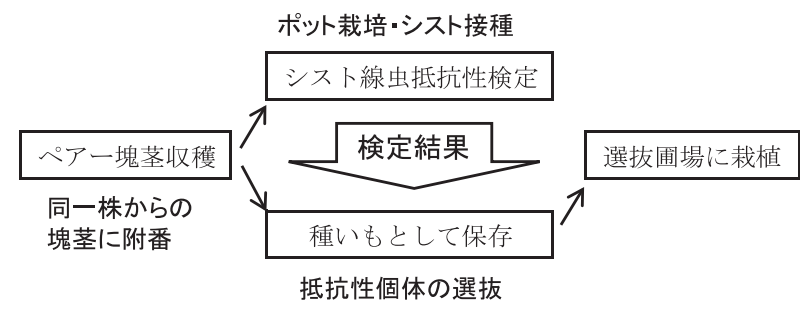

図 2.ペアー塊茎法によるシストセンチュウ抵抗性の検定.
実生世代での抵抗性検定を行わず，生産力予備検定終了 後に確認の検定を行うのみで選抜効率が飛躍的に向上し た（森・梅村 1992）.

\section{4.「Tunika」を交配親とする $\mathrm{Gr}$ 抵抗性品種「キ タアカリ」の育成}

1972 年以降の約 20 年間は $\mathrm{Gr}$ 抵抗性の導入を最優先 としたため，それ以前の育成品種に比べ収量が劣るばか りでなく, いもの外観や調理品質, 油加工適性捻よびで ん粉品質など利用特性も犠牲にせざるを得なかった。 こ の中でも，「Tunika」を母本とする交配からは比較的優良 な後代が得られ，Gr に抵抗性を有する多数の優良品種が 育成された。「トヨアカリ」は国内で初めて育成した抵抗 性品種で,「ッニカ」より高でん粉多収のでん粉原料用品 種である.「キタアカリ」は赤目の外観で黄色粉質の肉質 の生食用品種,「エゾアカリ」は黄白色粘質の肉質で煮崩 孔ず煮物に向く生食用品種，「ムサマル」はフライ適性の 優れる加工用品種である.ささらにでん粉原料用の「サク ラフブキ」は「トヨアカリ」を父とし，フライドポテト 向け加工用の「こが社丸」は「ムサマル」を母とする育 成品種である.

「キタアカリ」は，1975 年に「男爵薯」を母，旧東ド イッの Gr 抵抗性品種「Tunika」を父として交配し, 生食 用として国内初めて育成された $\mathrm{Gr}$ 抵抗性品種で, 1987 年に農林認定された（表 3)。「キタアカリ」は，「ばれい しょ北海 63 号」として現地試験に 5 年間供試されてお り, 通常は $2 \sim 3$ 年で可否が決するが倍の年限を要してい る. 当初は早生のでん粉原料用として評価を進めたが, 收量に敃いて既存品種に比べ優位性を見出すことができ なかった，ところが後志地方の現地に打いて食味が優れ ることを高く評価され，生食用として再評価することと なり試験が継続された，育成場が品種化を諦めようとし たとき，現地において当初目的とは異なる用途が見出さ れ，農林認定まで至った強運の品種である（表 3).

表 2. $\mathrm{Gr}$ 抵抗性遺伝子 $\mathrm{H}_{1}$ を三重式に持つ母本系統の選抜

\begin{tabular}{|c|c|c|c|c|c|c|}
\hline \multirow{2}{*}{ 交配組合せ $+\times \sigma^{7}$} & \multicolumn{2}{|c|}{ 個体数 } & \multirow{2}{*}{ 抵抗性頻度（\%） } & \multicolumn{2}{|c|}{ 抵抗性期待值 1) } & \multirow{2}{*}{ 推測遺伝子型 } \\
\hline & 抵抗性 & 罹病性 & & I & II & \\
\hline トヨシロ × R392-6 & 55 & 95 & 36.7 & 50.0 & 46.4 & $\mathrm{~h}_{1} \mathrm{~h}_{1} \mathrm{~h}_{1} \mathrm{~h}_{1} \times \mathrm{H}_{1} \mathrm{~h}_{1} \mathrm{~h}_{1} \mathrm{~h}_{1}$ \\
\hline トヨシロ×R392-36 & 92 & 107 & 46.2 & 50.0 & 46.4 & $\mathrm{~h}_{1} \mathrm{~h}_{1} \mathrm{~h}_{1} \mathrm{~h}_{1} \times \mathrm{H}_{1} \mathrm{~h}_{1} \mathrm{~h}_{1} \mathrm{~h}_{1}$ \\
\hline トヨシロ× R392-3 & 180 & 53 & 77.3 & 83.3 & 78.6 & $\mathrm{~h}_{1} \mathrm{~h}_{1} \mathrm{~h}_{1} \mathrm{~h}_{1} \times \mathrm{H}_{1} \mathrm{H}_{1} \mathrm{~h}_{1} \mathrm{~h}_{1}$ \\
\hline トヨシロ × R392-12 & 177 & 23 & 88.5 & 83.3 & 78.6 & $\mathrm{~h}_{1} \mathrm{~h}_{1} \mathrm{~h}_{1} \mathrm{~h}_{1} \times \mathrm{H}_{1} \mathrm{H}_{1} \mathrm{~h}_{1} \mathrm{~h}_{1}$ \\
\hline トヨシロ × R392-27 & 170 & 28 & 85.9 & 83.3 & 78.6 & $\mathrm{~h}_{1} \mathrm{~h}_{1} \mathrm{~h}_{1} \mathrm{~h}_{1} \times \mathrm{H}_{1} \mathrm{H}_{1} \mathrm{~h}_{1} \mathrm{~h}_{1}$ \\
\hline トヨシロ×R392-25 & 189 & 11 & 94.5 & 100.0 & 96.4 & $\mathrm{~h}_{1} \mathrm{~h}_{1} \mathrm{~h}_{1} \mathrm{~h}_{1} \times \mathrm{H}_{1} \mathrm{H}_{1} \mathrm{H}_{1} \mathrm{~h}_{1}$ \\
\hline トヨシロ × R392-50 & 191 & 9 & 95.5 & 100.0 & 96.4 & $\mathrm{~h}_{1} \mathrm{~h}_{1} \mathrm{~h}_{1} \mathrm{~h}_{1} \times \mathrm{H}_{1} \mathrm{H}_{1} \mathrm{H}_{1} \mathrm{~h}_{1}$ \\
\hline $\mathrm{R} 392-27 \times \mathrm{R} 392-50$ & 206 & 5 & 97.6 & 100.0 & 99.2 & $\mathrm{H}_{1} \mathrm{H}_{1} \mathrm{~h}_{1} \mathrm{~h}_{1} \times \mathrm{H}_{1} \mathrm{H}_{1} \mathrm{H}_{1} \mathrm{~h}_{1}$ \\
\hline
\end{tabular}

1): (I) Random chromosome assortment model, (II) Random chromatid assortment model.

Gr 抵抗性検定 : 実生幼苗に卵・幼虫が 200 個体以上 /ポットを土㙥接種し，接種後 7 8 週目に，根に雌成虫の寄生が認められない個 体を抵抗性と判定. 
表 3.「キタアカリ」，「とらや」执よび「さやか」の育成・登録に関する基本情報

\begin{tabular}{|c|c|c|c|}
\hline 項目 & キタアカリ & とらや & さやか \\
\hline 農林認定 & $\begin{array}{c}\text { ばれいしょ農林 } 29 \text { 号 } \\
\quad(1987 \text { 年 } 6 \text { 月 })\end{array}$ & $\begin{array}{c}\text { ばれいしょ農林 } 31 \text { 号 } \\
\quad(1992 \text { 年 } 7 \text { 月 })\end{array}$ & $\begin{array}{c}\text { ばれいしょ農林 } 36 \text { 号 } \\
\quad(1995 \text { 年 } 9 \text { 月 })\end{array}$ \\
\hline 品種登録 & $\begin{array}{c}\text { 第 } 1812 \text { 号 } \\
(1988 \text { 年 } 12 \text { 月 } 13 \text { 日) }\end{array}$ & $\begin{array}{c}\text { 第 } 4232 \text { 号 } \\
\text { (1995 年 } 1 \text { 月 } 26 \text { 日) }\end{array}$ & $\begin{array}{c}\text { 第 } 6027 \text { 号 } \\
\text { (1998 年 } 1 \text { 月 } 22 \text { 日) }\end{array}$ \\
\hline 地方番号 & ばれいしょ北海 63 号 & ばれいしょ北海 70 号 & ばれいしょ北海 74 号 \\
\hline 交配年 & 1975 年 & 1981 年 & 1983 年 \\
\hline 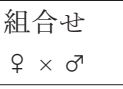 & 男爵薯 × Tunika & R392-50 $\times$ WB77025-2 & Pentland Dell $\times$ R392-50 \\
\hline 命名由来 & $\begin{array}{l}\text { 北海道で栽培され，線虫被害から } \\
\text { 守る希望を表す }\end{array}$ & $\begin{array}{l}\text { 主産地を期待している道南地方の } \\
\text { 湖の名前「洞爺湖」に因む }\end{array}$ & $\begin{array}{l}\text { えぐ味の元となるグリコアルカロイド含量が少なく, } \\
\text { 爽やかな風味と白皮白肉で変色が少ないことを表現 }\end{array}$ \\
\hline 育成者 & $\begin{array}{l}\text { 西部幸男，坂口進，入倉幸雄， } \\
\text { 梅村芳樹，奥山善直，佐藤正人， } \\
\text { 森元幸，内澤啓，気賀沢和男， } \\
\text { 稲垣春郎 }\end{array}$ & $\begin{array}{l}\text { 梅村芳樹, 佐藤正人, 森元幸, } \\
\text { 米田勉, 西部幸男, 入倉幸雄, } \\
\text { 内澤啓，三井康，清水啓 }\end{array}$ & $\begin{array}{l}\text { 梅村芳樹, 中尾敬, 小原明子, 吉田勉, 森元幸, } \\
\text { 木村鉄也，佐藤正人，西部幸男，米田勉，入倉幸雄， } \\
\text { 内澤啓，石井現相，三井康，清水啓 }\end{array}$ \\
\hline
\end{tabular}

交配場所：農林水産省北海道農業試験場（北海道恵庭市島松）.

「キタアカリ」は，「男爵薯」と活渂同様な生育特性を 有する早生品種である（表 4)。地上部は，「男爵薯」に 比べ全体的に緑色が淡い印象を受ける。収量は「男爵薯」 に比べ 10\%程度多収で，でん粉価は同等である（育成地 では $1 \%$ 程度高い)。いも数が多いため，「男爵薯」より小 玉が多いとの印象を受ける。「男爵薯」より施肥レベルを 上げることにより大玉の比率は上がるが，褐色心腐など の内部異常発生のリスクは増加するので注意が必要であ る. いもの休眠期間が「男爵薯」に比べ短いため，年に より 11 月頃から萌芽をするので注意が必要である。いも の形状は「男爵薯」に比べ厚みが少なく扁球形で, 皮色 は白黄で目が赤い. 肉色は黄で肉質はやや粉, 煮くずれ は「男爵薯」より多いが火の通りは早く, 調理後黒変は 生じない。また「男爵薯」に比べビタミン C 含量が多 い.「男爵薯」に比べ貯蔵中の品質変化が大きく，低温で 越年すると粉質度が低下し，甘味は増加する。通常の貯 蔵で翌年の春以降まで貯蔵すると,「男爵薯」に比べいも に㱀が寄り，萎びが多く，萌芽も早い。ただし，雪室貯 蔵やCA 貯蔵をすれば長期貯蔵可能であり，でん粉が糖 化した甘味を特徴として販売される場合もある.

\section{5.「R392-50」を交配親とする $\mathrm{Gr}$ 抵抗性品種「と うや」,「さやか」の育成}

Gr 抵抗性遺伝子を 3 重式に持つ「R392-50」を用いて 効率的な育種を進め,「とらや」,「さやか」,「アーリース ターチ」等多数の優良品種が育成された.「とらや」と 「さや」は Gr 抵抗性品種育成の基幹母本として利用さ れ，多数の調理加工用品種が育成されている。「とらや」 の後代からは,「アイユタカ」,「らんらんチップ」,「ゆき つぶら」，「きたかむい」等が育成され，「さやか」の後代 からは，「きたひめ」，「はるか」，「ハロームーン」等が育 成されている。

\section{(1)「とうや」}

「とらや」は，1981 年に早生で良形の Gr 抵抗性母本系 統「R392-50」を母, Y モザイク病抵抗性の種間雑種系統 「WB77025-2」を父とする交配から育成され，1992 年に 農林認定された（表 3)。「とらや」は，「ばれいしょ北海 70 号」として現地試験に供試されており, 有望系統の成 績検討に拈いて「男爵薯」に比べ多収ではあるがでん粉 価が $1 \%$ 程度低いことが問題にされた。 シニアの研究者 では「バレイショの美味しさ＝ホクホク感＝高でん粉価」 との意識が強く，さらには「塩煮にしても粉を吹かない」 との指摘もあり，当時ですら「塩煮は過去の料理」との 状況のなかで，否定的な見解が出された，バレイショ育 種グループの責任者は故梅村芳樹室長であり，それぞれ の品種特性に合わせた料理を提言し普及をはかる熱心さ で有名な人物であった。「北海道産の多くは本州に出荷さ れ，誰も塩煮にして食べない。煮物やシチューなどでは 煮崩れの少ないバレイショが求められている.」と説得を 行い, ようやく北海道の優良品種に認定された。

「とらや」は，「男爵薯」と同じ早生品種であり，「ワセ シロ」と同様に早期出荷向けとして利用される (表 4). 「男爵薯」より茎長がやや長く, 茎は太く数は少なく, 草 型はやや直立し, 地上部全体として頑丈な草姿である。 収量は「男爵薯」や「口セシロ」より多く，でん粉価は 「男爵薯」より $0.5 \sim 1.0 \%$ 程度低い. 株当たりいも数は少 ないが大いもが多く，上小も平均一個重は「男爵薯」よ り大きく「ワセシロ」よりやや小さい. 早掘り時の大い も比率も「ワセシロ」並である。いもの粒ぞろいは良い. いもの休眠は「男爵薯」並でやや長い、いもの肥大開始 は「男爵薯」より遅いが，その後の肥大は「ワセシロ」 と同様に早い, 多肥や疎植では, いもの大粒化が著しく, 裂開や褐色心腐（中心部えそ型）が発生する。そこで, 「男爵薯」と同レベルの施肥では多すぎる場合もあること から少肥とし, 密植により単位面積当たり茎数を確保し, 
表 4.「キタアカリ」,「とらや」扤よび「さやか」の主要特性概要

\begin{tabular}{|c|c|c|c|c|}
\hline 品種名 & キタアカリ & とうや & さやか & 男爵薯 \\
\hline 萌芽期（月/日） & $5 / 31$ & $5 / 30$ & $5 / 31$ & $5 / 30$ \\
\hline 茎葉枯凋期（月/日） & $9 / 3$ & $8 / 29$ & $9 / 13$ & $9 / 1$ \\
\hline 早晚性 & 早生 & 早生 & 中生 & 早生 \\
\hline そら性（草型） & 中間 & やや直立 & やや開張 & 中間 \\
\hline 茎の太さ & 中 & 太 & やや太 & 中 \\
\hline 小葉の大きさ & やや大 & 大 & 中 & 大 \\
\hline 花の色 & 赤紫系 & 白 & 白 & 赤紫系 \\
\hline 花数 & 中 & 中 & 少 & 多 \\
\hline 茎長（cm） & 58 & 53 & 59 & 48 \\
\hline 茎数（本/株） & 4.6 & 4.1 & 2.0 & 4.6 \\
\hline いもの休眠期間 & 中 & やや長 & やや長 & やや長 \\
\hline ストロン長 & 短 & 中 & 中 & 短 \\
\hline いもの形 & 扁球 & 球 & 卵 & 球 \\
\hline 目の深さ & 中 & 浅 & 浅 & 深 \\
\hline 皮色 & 白黄（目：赤） & 黄褐 & 白 & 白黄 \\
\hline 肉色 & 黄 & 黄 & 白 & 白 \\
\hline 上いも数（個/株） & 13.2 & 10.7 & 9.6 & 12.1 \\
\hline 平均 1 個重（g） & 81 & 113 & 126 & 80 \\
\hline 上いも重（ $\mathrm{kg} / 10 \mathrm{a} ）$ & 4,705 & 4,746 & 5,286 & 4,283 \\
\hline 「男爵薯」比（\%） & 110 & 111 & 123 & 100 \\
\hline でん粉価（\%） & 14.5 & 13.6 & 14.2 & 14.8 \\
\hline Gr 抵抗性 & 強 $\left(\mathrm{H}_{1}\right)$ & 強 $\left(\mathrm{H}_{1}\right)$ & 強 $\left(\mathrm{H}_{1}\right)$ & 弱 (h) \\
\hline 疫病抵抗性 & 弱 & 弱 & 弱 & 弱 \\
\hline そらか病抵抗性 & 弱 & 弱 & 弱 & 弱 \\
\hline 粉状々らか病抵抗性 & 弱 & 弱 & 弱 & やや弱 \\
\hline 青枯病抵抗性 & 弱 & やや強 & 弱 & 弱 \\
\hline 打撲耐性 & やや弱 & 中 & 強 & 弱 \\
\hline 剥皮後褐変 & 少 & 微 & 微 & 中 \\
\hline 調理後黒変 ～ & 無 & 無 & 微 & 少 \\
\hline 水煮時の煮くずれ & 中 & 少 & 少 & 中 \\
\hline 水煮時の肉質 & やや粉 & やや粘 & 中 & やや粉 \\
\hline チップ・フライの褐変 & 中 & 多 & 中 & 中 \\
\hline
\end{tabular}

調査場所: 北海道農業研究センター (河西郡芽室町).

調査年次 : 2011 2017 年の平均.

施肥量 $\left(\mathrm{N}, \mathrm{P}_{2} \mathrm{O}_{5}, \mathrm{~K}_{2} \mathrm{O}, \mathrm{MgO}: \mathrm{kg} / 10 \mathrm{a}\right): 6.0,17.0,10.2,5.1$.

栽植密度: 畦間 $75 \mathrm{~cm}$, 株間 $30 \mathrm{~cm}$.

植付: 5 月上旬, 収穫 : 9 月下旬.

上小も重 : $20 \mathrm{~g}$ 以上のいも収量.

でん粉価：ライマン価と同義で（比重－1.05）×214.5+7.5 で算出.

特性調査: 北海道農業研究センタ一の常法による.

急激な肥大を抑制することにより裂開と内部異常を防ぐ 必要がある。病害抵抗性は, 青枯病はやや強であるが, 粉状々らか病には弱く土壤水分が高くなりやすい水田転 換畑なぞでの作付けには適さない，ウイルス病の自然感 染率は低い、いもが球形で, 大いもの揃いが良く目が浅 いので剥皮しやすく，また酵素による剥皮褐変も少ない ので一次加工などの業務用にも適する，皮色は黄褐で表 皮がやや粗く, 肉色は黄である. 肉質はやや粘質で, 舌 ざわりは滑らかである，煮くずれは「男爵薯」や「ワ七 シロ」より少なく, 調理後黒変はみられない, 食味の評 価は好みによって異なり, 粉質好みの人は低く, 粘質を 好む人は高く評価する傾向にある。学ぐ味の元となるグ
リコアルカロイド含量は「男爵薯」より多く, 特に曝光 による増加が「メークイン」並に多い，このため，収穫 以降の扱いや貯蔵さらに流通場面に沶いて, 光に曝さな い管理が特に品質維持の上で重要である.

\section{（2）さやか}

「さやか」は 1983 年にイギリスの大粒多収品種「Pentland Dell」を母, Gr 抵抗性母本系統「R392-50」を父とする交 配から育成され，1995 年に農林認定された（表 3）１１990 年頃から業務向けポテトサラダの需要が増加し, 加工実 需に原料を供給する十勝地方の農業団体からこれまでと は異なる品質特性を有する品種育成の要望を受けた。従 
来は「でん粉価が高いほど高品質である」が常識であっ たが，でん粉価は核どほどでも「白肉に加え，大粒で皮 を剥きやすい」ことを第一義とする新品種が求められた. 「さやか」は，「ぼれいしょ北海 74 号」として現地試験に 供試されて扣り, 試験研究・普及組織よりむしろ生産現 場での評価が高かった。 これは多収性で出荷規格の歩留 りが高いことに加え，ポテトサラダを加工する実需での 高評価を反映している。「さやか」は大粒で目が浅いため 剥皮歩留りが高く，いもが打撲に強いことから不良部位 を取り除くトリミングに必要な人件費と残椬の処理費用 が少なくなると評価された。

「さやか」は，「男爵薯」より 2 週間程度遅い中生品種 に属する（表 4)，茎長が中程度で分枝は少なくやや開張 の草型で，地上部は頼りないとの印象を受ける。収量は 「男爵薯」より多く，いも数は少なく平均一個重が大きい 個重型品種である。でん粉価は，「男爵薯」と同等ないし わずかに低い、いもの形は卵形で，表皮は「男爵薯」よ り白い白色で滑らかである。粒ぞろいが良く，いもの目 が浅く凸凹が少ないため外観は良い。肉色は「男爵薯」 と同様に白い, 中心空洞, 褐色心腐, 黒色心腐など内部 異常はほとんど発生することが無く，二次生長の発生は 「男爵薯」より少ない。いもの休眠期間は「男爵薯」並の やや長で，貯蔵性が良い，多肥による黄変期の遅れや茎 の徒長は少なく，増収効果は高い. 目が浅く大粒の「さ やか」は，同じ重量割合までヤスリピーラーで剥皮した とき,「男爵薯」に比べ単位重量当たりのトリミング回数 は $1 / 3$ 以下となり，人件費の節減効果は大きい。剥皮後 褐変は「男爵薯」より少ない. 肉質は中で煮くずれは「男 爵薯」より少ない. 水者放冷後の調理後黒変は「男爵薯」 より少なく，調理特性に優れている，食味は「男爵薯」 より癖が無くあっさりしている. えぐ味の元となるグリ コアルカロイド含量は「男爵薯」よりやや少なく, いも を光に曝した場合のグリコアルカロイドの生成量は「男 爵薯」より明らかに少なく, 緑化の進みも少ない.

\section{6. 普及経過と現状}

「キタアカリ」は，良食味や高ビタミン C が消費者に 多徐々に知られるよらになり，「黄金男爵」，「栗じゃが」 などの商品名で売られていることもある。品種の登録時 に，いもの皮色が目の部分だけ赤く肉は黄色であり，主 要品種の「男爵薯」と比べ外観が異なることから青果市 場や消費者に受容されるかとの議論があった。「男爵薯」 以外の青果販売は単なるバレイショとして品種名を付さ ずに販売される傾向があるが，一目で分かる区別性から 品種名を明記した販売が行われ，2000 年には Gr 抵抗性 品種の中で栽培面積が千 ha を越えた初めての品種となっ た（2000 年：1,287 ha）。その後，増加を続け 2015 年全 国に拉ける作付面積は 3,928 ha となり，北海道ばかりで なく全国で栽培されている。
「とらや」は，「黄爵」の商品名で売られていることも ある。「とらや」が育成された頃, 北見地方の端野地域で は「ワセシロ」を 8 月上旬から早期出荷していた。 JA が 中心となって「ワセシロ」に代わる Gr 抵抗性品種を模索 し，「とらや」を取り上げて施肥や栽植密度の試行錯誤を 行い産地化に成功した. 端野での取り組みを最初として, 十勝地方の幕別地域などでの産地化も加わり, 2005 年に は栽培面積が千 ha を越えた（2005 年：1,203 ha）。北海 道での早期出荷向け栽培ばかりでなく，本州の春作に括 いても作付けが増加して扮り，2015 年全国に拈ける作付 面積は 1,997 ha である.

「さやか」は，いもの凹凸が少ないため剥皮歩留が高 く, 主にサラダ原料として利用されている. 品種の登録 後, 実需からの工場ライン規模による加工評価に対する 強い要望に応え, マイクロチューバ（キリン社産）を用 いた現地評価用種いもの生産を行い, 同時に種苗管理セ ンターに扣いて原原種の緊急増殖を行った。一般栽培は 幕別・芽室・土幌など十勝地域の大産地が中心となり急 速に栽培面積を伸ばし，2005 年には千 haを越えた（2005 年 : 1,097 ha). その後, 2 千 ha 近くまで増加したが漸減 し，2015 年全国に打ける作付面積は，北海道を中心に 1,481 ha である.

\section{7. 今後の課題と展望}

需要動向の変化に対応した $\mathrm{Gr}$ 抵抗性品種の育成は, $\lceil$ Tunika」や「R392-50」を直接の親とする段階から，育 成品種や有望系統をさらに母本とした世代となっており, 調理加工適性が向上した 2000 年以降の育成品種も普及 段階に至っている (Mori 2008)。このように，1972 年に 初めて国内で発生が確認され $\mathrm{Gr}$ へ㕕種的な対応は, 着実に進められている (Mori et al. 2015). この間, 海外 から新たな特性を有する $\mathrm{Gr}$ 抵抗性品種の導入が進められ るとともに Gr 抵抗性の検定法では「カップ検定法」が 開発されて小スペースの省力化がなされ, さらに DNA マーカーも利用されるよらになった（Asano et al. 2012）.

このよらな状況で, 我が国で初めてのジャガイモシロ シストセンチュウ（以下 Gp）の発生が，2015 年 8 月に 北海道網走市で確認され新たな脅威が出現した。前出 2 . の育種戦略で述べた「(4)異種等の発生に備え来歴の異な る抵抗性遺伝資源を導入して母本を育成」に従い, 細々 之近縁野生種・種間雑種の利用や遺伝資源の導入等を進 めていたが (入倉ら 1987), 新規発生確認の衝撃は大き い. 1972 年に発生確認された Gr に対する抵抗性には強 力な主働遺伝子が存在し, これを利用して完全な Gr 抵抗 性品種が育成されている（森 2009）。乙かし2015 年に発 生確認された $\mathrm{Gp}$ に対する抵抗性は微働遺伝子によるも ので，完全な抵抗性を示す遺伝子は世界的に知られてい ない.このため複数の抵抗性遺伝子を組み合わせ，異な る遺伝子の効果を積み重水て抵抗性品種を育成する必要 
がある. Gp 抵抗性品種の育成では，抵抗性の程度を 10 段階に評価して预り，簡易な抵抗性検定法は確立されて おらず，現有の遺伝資源では完全な抵抗性品種を育成で きないなど，多くの困難さがある(浅野ら 2017)。Gr 発 生が初めて確認された 1972 年当時に比べ, 現在は遺伝情 報をDNA レベルで解析でき，ゲノム情報を利用した育 種が展開可能である. この進歩を利用して, 困難さが克 服されることを期待する。

\section{謝 辞}

1972 年の $\mathrm{Gr}$ 発生確認以降, 農業改良普及センターや 農業試験場, 生産団体なぞの多くの技術者・研究者が, 現地調查や防除研究さらに抵抗性品種育成に取り組んで きた。初期の緊急対応を進めた担当者は現職を退きまた 鬼籍に入るなど 45 年あまりの年月が流れたが，現場での 対策と研究開発は絶兄間なく継続されている。本受賞は これまで様々な立場で活躍した数多くの関係者が成し遂 げた業績に対するものであり，すべての関係者の偉大な 功績に敬意を払い，皆様に心より扔礼を申し上げる。

\section{バレイショ育種グループ}

森 元幸，梅村芳樹，西部幸男，坂口 進, 入倉幸雄, 奥山善直, 高田明子, 木村鉄也, 米田 勉, 吉田 勉, 中尾 敬, 佐藤正人, 内澤 啓, 石井現相, 気賀沢和男, 稲垣春郎, 三井 康, 清水 啓

\section{引用文献}

相場 聡・稻垣春郎（1992）ジャガイモシストセンチュウ，線 虫研究の歩及. 日本線虫研究会: 121-124.

Asano, K., A. Kobayashi, S. Tsuda, M. Nishinaka and S. Tamiya (2012) Breed. Sci. 62: 142-150.

浅野賢治・串田篤彦・奈良部孝（2017）ジャガイモシロシスト センチュウ対策に係る海外先進地事例調查報告, 農研機構 研究報告北海道農業研究センター 206: 21-48.

Brodie, B.B. (2001) Potato cyst nematodes. In: Compendium of Potato Diseases, second edition (edited by W.R. Stevenson, R. Loria, G.D. Franc and D.P. Weingartner). APS Press, St. Paul, Minnesota, USA. 48-50.

稻垣春郎（1980）ジャガイモシストセンチュウの防除任関する 研究, 研究成果. 農林水産技術会議事務局 127: 106-110.

稻垣春郎（1984）北海道農試研報 139: 73-144.

入倉幸雄・森 元幸・西部幸男（1987）生物学的手法に上る病 害虫新防除技術の開発滛関する総合研究, 研究成果. 農林 水産技術会議事務局 189 ：92-94.

串田篤彦・百田洋二 (2005) 日本線虫学会誌 35: 87-90.

Mori, K., K. Asano, S. Tamiya, T. Nakao and M. Mori (2015) Breed. Sci. 65: 3-16.

森 元幸・梅村芳樹（1992）ジャガイモシストセンチュウ抵抗 性品種の育成, 線虫研究の歩及, 日本線虫研究会: 272-276.

Mori, M. (2008) Gamma Field Symposia (Institute of Radiation Breeding NIAS, Japan) 47: 49-57.

森 元幸 (2009) 北農 76: 7-13.

森 元幸 (2015) 農業 1594: 45-55.

村山大記（1981）馬鈴しょの大敵ジャガイモシストセンチュウ の防ぎ方, 北海道澱粉工業協会 : 24 .

西部幸男・稲垣春郎（1980）ジャガイモシストセンチュウの防 除北関する研究, 研究成果. 農林水産技術会議事務局 127: 102-114.

Ross, H. (1986) Potato Breeding — problems and perspectives. Verlag Paul Parey, Berlin and Hamburg.

山田英一（1987）北海道立農試報告 61: 1-98. 